\title{
URIDINE INCORPORATION AND PYRUVATE METABOLISM IN RABBIT EGGS CULTURED IN VITRO AT NORMAL AND ELEVATED TEMPERATURES
}

\author{
T. L. GRIBLEZ AND C. W. ALLISTON \\ Department of Animal Sciences, Purdue University, \\ West Lafayette, Indiana 47907, U.S.A.
}

(Received 21st May 1973)

\begin{abstract}
Summary. Effects of elevated maternal body temperature upon incorporation of an RNA precursor by rabbit eggs were evaluated by culture in vitro at 39.0 or $40.3^{\circ} \mathrm{C}$, temperatures comparable to rectal temperatures of rabbits in normal and elevated ambient temperatures. One-cell fertilized eggs incorporated significantly less $\left[{ }^{3} \mathrm{H}\right]$ uridine during culture at the higher temperature, indicating a depression of RNA synthesis. Uridine incorporation was not significantly decreased when two-cell ova were incubated with $\left[{ }^{3} \mathrm{H}\right]$ uridine after completion of the first cleavage, but was decreased in two-cell ova that had been subjected to the higher temperature only while in the one-cell stage of development. The observed reductions in uridine incorporation at the higher temperature were not accompanied by a decrease in energy production as determined by $\mathrm{CO}_{2}$ production from $\left[{ }^{14} \mathrm{C}\right]$ pyruvic acid. These results suggest that such alterations of regulatory function are associated with the sensitivity of the early zygote to thermal stress and is a mechanism by which elevated maternal body temperatures adversely influence subsequent embryonic development.
\end{abstract}

\section{INTRODUCTION}

Increased embryonic mortality following exposure of the female to elevated ambient temperature conditions has been observed in a number of independent investigations. Maternal hyperthermia associated with such stress may exert an influence through 'indirect' actions such as endocrine function(s) or 'direct' effects of temperature per se upon the gamete and/or zygote. The one-cell fertilized rabbit egg is more susceptible to such 'direct' effects than is the twocell egg (Alliston, Howarth \& Ulberg, 1965). Maternal heat stress appears to decrease RNA synthesis (Elliott, 1968; Bellvé, 1972), a finding which appears consistent with delayed embryonic mortality subsequent to thermal stress.

This study was initiated to determine the effects of hyperthermia on the incorporation of an RNA precursor during the period when the fertilized rabbit egg is most sensitive to thermal stress. 


\section{MATERIALS AND METHODS}

The breeding colony of New Zealand White rabbits was maintained at ambient conditions of $21^{\circ} \mathrm{C}, 50$ to $65 \%$ relative humidity and $14 \mathrm{hr}$ daily illumination. Females were naturally mated and killed either $19 \mathrm{hr}$ post coitum (p.c.) to obtain one-cell eggs or $24 \mathrm{hr}$ p.c. to obtain two-cell eggs.

Eggs were flushed from the oviducts with sterile saline and examined with a stereomicroscope for morphological appearance and evidence of fertilization. Half the eggs from each donor were cultured separately at either $39^{\circ} \mathrm{C}$ or $40^{\circ} \mathrm{C}$, temperatures comparable to rectal temperatures of this rabbit colony at normal $\left(21^{\circ} \mathrm{C}\right)$ and elevated $\left(32^{\circ} \mathrm{C}\right)$ ambient conditions, respectively (Miller, 1971).

Evaluation of the direct effect of elevated maternal temperature upon RNA synthesis was made in vitro, using a modification of the method described by Manes (1969). One-cell eggs were placed in $0.1 \mathrm{ml}$ rabbit serum containing $40 \mu \mathrm{Ci}\left[{ }^{3} \mathrm{H}\right]$ uridine (International Chemical and Nuclear Corporation)/ml, gassed with $5 \% \mathrm{CO}_{2}$ in air and cultured for $4 \mathrm{hr}$. In determinations involving two-cell eggs, the level of isotope was reduced to $20 \mu \mathrm{Ci} / \mathrm{ml}$ because of the greater rate of RNA synthesis. Immediately after culture, the eggs were reexamined microscopically and washed three times in chilled saline containing 100 -fold excess of unlabelled uridine as a 'chase' for the unincorporated uridine. The eggs were ruptured by rapidly freezing and thawing three times and the contents were precipitated with cold $10 \%$ trichloroacetic acid (TCA). The precipitate was collected on filter paper and washed with additional TCA and ethanol-ether. The dried samples were counted four times at $50 \mathrm{~min}$ per counting period using PPO-POPOP in toluene because of the ratio of sample counts to background resulting from small numbers of eggs per determination.

The rate of $\mathrm{CO}_{2}$ production from pyruvic acid was determined by modification of the method reported by Brinster (1967). Eggs were cultured for $4 \mathrm{hr}$ at either 39.0 or $40.3^{\circ} \mathrm{C}$ in $0.1 \mathrm{ml}$ rabbit serum containing $10 \mu \mathrm{Ci}\left[{ }^{14} \mathrm{C}\right]$ pyruvic acid (International Chemical and Nuclear Corporation)/ml. Metabolic activity was stopped by addition of $0.1 \mathrm{ml}$ of $1 \mathrm{~N}-\mathrm{H}_{2} \mathrm{SO}_{4}$ and the $\mathrm{CO}_{2}$ absorbed by $1.0 \mathrm{ml}$ hyamine hydroxide. Samples were counted three times at $5 \mathrm{~min}$ per counting period, using PPO-POPOP in toluene.

Rates of uridine incorporation and pyruvate metabolism were expressed as counts $/ \mathrm{min} / \mathrm{egg}$ and analysed using the paired $t$ test.

\section{RESULTS}

Preliminary observations included transfer of limited numbers of cultured eggs to recipient females. No gross effects of culture techniques or isotope were evident in the number or appearance of young born or their ability to reproduce at maturity, but fewer young were born from eggs cultured at the higher temperature $\left(7 / 15\right.$ versus $\left.10 / 13 ; \chi^{2}=1.55, P>0.05\right)$.

One-cell eggs cultured at $40 \cdot 3^{\circ} \mathrm{C}$ incorporated less uridine, indicating a depression of RNA synthesis at the higher temperature (Table 1). No difference 
Table 1. Incorporation of $\left[{ }^{3} \mathrm{H}\right]$ uridine by fertilized rabbit eggs during culture in vitro at $39 \cdot 0$ and $40 \cdot 3^{\circ} \mathrm{C}$

\begin{tabular}{|c|c|c|c|c|}
\hline \multirow{2}{*}{$\begin{array}{l}\text { Cell stage } \\
\text { at recovery }\end{array}$} & \multirow{2}{*}{$\begin{array}{c}\text { Culture } \\
\text { temperature } \\
\left({ }^{\circ} \mathrm{C}\right)\end{array}$} & \multirow{2}{*}{$\begin{array}{c}\text { No. of } \\
\text { determinations }\end{array}$} & \multicolumn{2}{|c|}{ Uridine incorporation } \\
\hline & & & $C t / \min / e g g$ & Difference $\pm S . E$. \\
\hline One-cell & $\begin{array}{l}39 \cdot 0 \\
40 \cdot 3\end{array}$ & $\begin{array}{l}21 \\
21\end{array}$ & $\begin{array}{l}2 \cdot 88 \\
1 \cdot 68\end{array}$ & $-1 \cdot 20 \pm 0.26 * *$ \\
\hline Two-cell & $\begin{array}{l}39 \cdot 0 \\
40 \cdot 3\end{array}$ & $\begin{array}{l}10 \\
10\end{array}$ & $\begin{array}{l}3.09 \\
3.01\end{array}$ & $-0.08 \pm 0.13$ \\
\hline
\end{tabular}

** $P<0.01$.

was noted between rates of uridine incorporation at the two temperatures with two-cell ova $(P>0.05)$.

Eggs from an additional group of donors were cultured at the two temperatures for a 4-hr period (19 to $23 \mathrm{hr}$ p.c.) in serum containing no isotope and were then cultured at $39.0^{\circ} \mathrm{C}$ for a subsequent $4-\mathrm{hr}$ period $(23$ to $27 \mathrm{hr}$ p.c.) in serum containing isotope. The results in Table 2 indicate a depression of uridine incorporation during later stages of development by those eggs exposed to the higher culture temperature only during the earlier development.

Table 2. Incorporation of $\left[{ }^{3} \mathrm{H}\right]$ uridine by rabbit eggs during culture in vitro at $39 \cdot 0^{\circ} \mathrm{C}$ subsequent to culture at $39 \cdot 0$ or $40 \cdot 3^{\circ} \mathrm{C}$

\begin{tabular}{|c|c|c|c|c|}
\hline \multicolumn{2}{|c|}{ Culture temperature $\left({ }^{\circ} \mathrm{C}\right)$} & \multirow{2}{*}{$\begin{array}{c}\text { No. of } \\
\text { determinations }\end{array}$} & \multicolumn{2}{|c|}{ Uridine incorporation } \\
\hline $\begin{array}{l}19 \text { to } 23 \text { hr p.c. } \\
(\text { no label) }\end{array}$ & $\begin{array}{c}23 \text { to } 27 \text { hr p.c. } \\
\text { (with label) }\end{array}$ & & $C t / \min / e g g$ & Differences $\pm S . E$. \\
\hline $\begin{array}{l}39 \cdot 0 \\
40 \cdot 3\end{array}$ & $\begin{array}{l}39 \cdot 0 \\
39 \cdot 0\end{array}$ & $\begin{array}{l}16 \\
16\end{array}$ & $\begin{array}{l}2.31 \\
1.99\end{array}$ & $-0.32 \pm 0.10^{* *}$ \\
\hline
\end{tabular}

Exposure of the egg to the elevated temperature before and during the initial cleavage therefore reduced its subsequent ability to incorporate uridine in the two-cell stage.

The rate of $\mathrm{CO}_{2}$ production from pyruvic acid by one-cell eggs was increased at the higher temperature (Table 3), under the same conditions that resulted in impairment of RNA synthesis. No difference in morphology or rate of cleavage due to culture temperature was observed in any of the studies.

Table 3. Carbon dioxide production from $\left[{ }^{14} \mathrm{C}\right]$ pyruvic acid by rabbit eggs during culture in vitro at $39 \cdot 0$ and $40 \cdot 3^{\circ} \mathrm{C}$

\begin{tabular}{c|c|c|c}
\hline $\begin{array}{c}\text { Culture } \\
\text { temperature } \\
\left({ }^{\circ} \mathrm{C}\right)\end{array}$ & $\begin{array}{c}\text { No. of } \\
\text { determinations }\end{array}$ & \multicolumn{2}{|c}{$\mathrm{CO}_{2}$ production } \\
\cline { 2 - 4 } 39.0 & 20 & Ct/min/egg/hr & Difference \pm S.E. \\
\hline 40.3 & 20 & 92.9 & 105.3 \\
\hline
\end{tabular}




\section{DISGUSSION}

Increased embryonic mortality following exposure of one-cell eggs to an elevated culture temperature has been reported, while no such increase in mortality was observed following the culture of two-cell eggs (Alliston et al., 1965). The rates of uridine incorporation by one- and two-cell eggs in the present study parallel the previous findings. An elevation of culture temperature by as little as $1.3^{\circ} \mathrm{C}$ altered the ability of the one-cell fertilized egg to incorporate uridine both during and subsequent to exposure to the high temperature. These results further confirm the unique susceptibility of the one-cell ovum to elevated temperature. The reduced incorporation of uridine cannot be accounted for by an impairment of energy production, as the rate of pyruvate metabolism is increased at the higher temperature.

The present findings agree with the retarded development (Elliott, Burfening \& Ulberg, 1968) and the reduced proportion of blastomeres capable of incorporating uridine (Bellvé, 1972) observed in heat-stressed mouse embryos. Sheean \& Ulberg (1971), however, reported an increased rate of uridine incorporation in mouse ova stressed under similar conditions.

Neither the formation of ribosomal RNA nor that of transfer RNA has been detected in the one-cell ovum (Manes, 1971). Autoradiographic studies following culture in $\left[{ }^{3} \mathrm{H}\right]$ uridine-containing media have reported only nuclear labelling to be present in the one-cell ovum and that cytoplasmic labelling was not observed until later cleavage stages (Mintz, 1962). In mammalian cells, approximately $80 \%$ of the total amount of RNA formed never leaves the nucleus and exists for less than $2 \frac{1}{2}$ hr (Shearer \& McCarthy, 1967). These RNA molecules that are present only in the nucleus have been implicated in the regulation of gene transcription. Congenital defects have been observed in young born subsequent to maternal hyperthermia induced during gestation (Edwards, 1969, 1971). It is likely that the uridine incorporation measured in the present study was nuclear in nature and involved with some aspect of gene expression or cell regulation. Not all the cells of stressed embryos die at the same time (Bellvé, 1972), and this differential response tends to support the hypothesis that detrimental effects of hyperthermia upon subsequent development involves impaired cell regulation.

\section{ACKNOWLEDGMENTS}

This investigation was supported in part by Public Health Service Research Grant 03009-03 from the National Institute of Child Health and Human Development and in part by National Science Foundation Traineeship No. GZ2362. Published as Journal Paper No. 5132 of the Indiana Agricultural Experiment Station.

\section{REFERENCES}

Alliston, C. W., Howarth, B., Jr \& Ulberg, L. C. (1965) Embryonic mortality following culture in vitro of one- and two-cell rabbit eggs at elevated temperatures. F. Reprod. Fert. 9, 337.

BeLLvE, A. R. (1972) Viability and survival of mouse embryos following parental exposure to high temperature. F. Reprod. Fert. 30, 71. 
BRINSTER, R. L. (1967) Carbon dioxide production from glucose by the preimplantation mouse embryo. Expl Cell Res. 47, 271.

EDWARDs, M. J. (1969) Congenital defects in guinea pigs: fetal resorptions, abortions and malformations following induced hyperthermia during early gestation. Teratology, 2, 313.

EDWARDs, M. J. (1971) The experimental production of arthrogryposis multiplex congenita in guinea-pigs by maternal hyperthermia during gestation. 7. Path. 104, 221.

Ei.Liotr, D. S. (1968) Developmental alterations in mouse embryos subjected to temperature stress in vivo during the first cell division. Ph. D. thesis, North Carolina State University at Raleigh. University Microfilm, Ann Arbor, Michigan.

Elliott, D. S., Burfening, P. J. \& Ulberg, L. C. (1968) Subsequent development during incubation of fertilized mouse ova stressed by high ambient temperature. 7. exp. Zool. 169, 481.

MANES, C. (1969) Nucleic acid synthesis in preimplantation rabbit embryos. I. Quantitative aspects, relationship to early morphogenesis and protein synthesis. 7. exp. Zool. 172, 303.

Manes, G. (1971) Nucleic acid synthesis in preimplantation rabbit embryos. II. Delayed synthesis of ribosomal RNA. 7. exp. Zool. 176, 87.

MILLER, H. L. (1971) The effects of high environmental temperatures and humidity upon reproduction and rectal temperature in the female rabbit. M.Sc. thesis, Purdue University, Lafayette, Indiana.

Mintz, B. (1962) Incorporation of nucleic acid and protein precursors by developing mouse eggs. Am. Zool. 2, 432.

Shearer, R. W. \& McCarthy, B. J. (1967) Evidence for ribonucleic acid molecules restricted to the cell nucleus. Biochemistry, 6, 283.

Sheean, L. A. \& Ulberg, L. C. (1971) ${ }^{3} \mathrm{H}$-uridine incorporation into stressed mouse ova. 7. Anim. Sci. 33, 269, Abstr. 